rodów między sobą. Dla nas ,nie pożądaj cudzego, nie czyń drugiemu, czego nie chcesz, aby tobie uczyniono" jest główną podstawą wszelkich stosunków społecznych i tak dobrze prawa narodów, jak i stosunków wzajemnych rodzin i jednostek, $z$ których narody się składają; bo my w swej prostocie nie umiemy pojąć, jakim sposobem to, co obowiązuje każdego w szczególności, nie ma w równejże sile obowiązywać ogółu całego $^{\text {" } 29}$ ).

Jeżeli chodzi o osoby społecznie szkodliwe, lub nie pełnowartościowe, lecz będące takimi bez własnej winy )kalecy, umysłowo upośledzeni; nieuleczalnie chorzy), to wzgląd na dobro społeczne może nakazywać ograniczenie ich praw, lecz nie wolno im odbierać życia lub ich kaleczyć, albo w jakikolwiek sposób ubliżać ich godności ludzkiej.

(Dok. nastąpi) .

Ks. JÓZEF ZAWADZKI.

\title{
W BAZYLICE GROBU ŚWIĘTEGO
}

W kruchcie Bazyliki, tuż u jej wejścia, siedzi stale na brudnym tapczanie dwóch muzułmanów-Arabów.

Codzień o godz. 11.30 ręcznym dzwonkiem dzwonią w rytmie urywanym przez kwadrans.

Ludzie spieszą zakończyć swe modlitwy i wychodzą. Wtedy Arabovie zamykają ogromne, drewniane, grubo i prymitywnie ciosane odrzwia wrót, zaryglowuja je, a potem przystawiają od wewnątrz drabinę, wchodzą po niej z kluczem i przekręcają go we wrotkach. Klucz to wymyślny, ma postać zawile kręconej śruby. Dziurka od klucza naumyślnie znajduje się tak wysoko, żeby nikt od zewnątrz nie mógł jej dosięgnąć ręką. Po dokonaniu tej codziennej czynności Arabowie otwierają maleńkie okienko w drzwiach i powracają na swe leże, gdzie albo drzemia, albo gryzą orzeszki wypluwając łupiny $\mathrm{z}$ ust.

Przy okienku staje wówczas mnich grecki i jeśli pielgrzymi przychodzą o tej porze i kołatają do wrót, żeby się dostać do wnętrza, ow mnich okazuje im swe brodate oblicze i objaśnia, najczęściej na migi, że Arabowie już wrota zamknęli i że je otworzą o pierwszej godzinie.

${ }^{29)}$ Odezwa do ludów Europy. 18. III. 1864. (cyt. Dubiecki Marian, Romuald Traugutt, 1863-1864, Kijów 1911, 198). 
Pielgrzymi odchodzą zdziwieni, że klucze od Bazyliki Grobu Swiętego, czczonej przez wszystkie chrześcijańskie wyznania, znajduja się w rękach Muzułmanów.

Ale taki stan rzeczy zastał generał Allenby i takim go pozostawił, kiedy po zdobyciu dnia 9. grudnia 1917 r. Jerozolimy, wzorem cesarza Herakliusza i księcia Godfryda, wszedł do Bazyliki boso krocząc po czerwonym suknie rozesłanym wzdłuż ulicy króla Dawida od Pałacu Heroda aż do Swiętego Grobu.

Stan zaś, który wówczas zastał, datuje od r. 1187, kiedy kalif Saladyn po zwycięstwie nad Krzyżowcami powierzył klucze świątyni dwon dostojnikom swego dworu: Jude i Nussebe. W ich to rodzie przechowuje się aż dotąd dziedziczny przywilej posiadania kluczów i sprawowania pieczy nad Bazyliką. 'Ich też muszą chrześcijańskie wyznania opłacać, godząc się biernie z ich historycznym stanem posiadañia. Wprawdzie mniej się on daje we znaki teraz, niż za czasów tureckich, kiedy ciż dwaj muzułmanie siadywali na ławie kamiennej przed wrotami i pobierali podatek wejściowy od pielgrzymów. Dziś wejście jest bezpłatne, a ława kamienna usunięta.

Kiedy ją usuwano, spostrzeżono, że przykrywała płytę grobowa z herbem i napisem. Płytę ochroniono kratą. Napis jest niewyraźny, ale jednak i dziś jeszcze możemy go odcyfrować. Czytamy: Philippe d'Aubigny - 1228. Był nim wychowawca królà angielskiego, Henryka III, uczestnik ostatniego pochodu krzyżowego za Fryderyka Barbarossy, ostatni rycerz krzyżowy tu pochowany.

Jedyny to grób i jedyny napis z czasów krzyżowych, jaki się tu zachował dzięki owej muzułmańskiej ławie kamiennej. Było tu przedtem kilkadziesiąt grobowców i sarkofagów znaczniejszych rycerzy chrześcijańskich oraz królów jerozolimskich, ich żon i dzieci. Ale mnisi greccy po straszliwym pożarze 1808 r., w którym się spalił dach Bazyliki, a mury jej poozerniały, siłą zawładnęli Świątynią, chociaż nikt im udziału w niej nie zabraniał i przebudowali ją niemal na twierdzę, zamurowując przepiękne kolumnady, aby skasować wolne przejścia. Przy tej sposobności usunęli wszystkie łacińskie nagrobki, a w tej liczbie także i dwa najstarsze dwóch pierwszych grobów jerozolimskich.

Chataubriand zwiedzając Bazylikę w r. 1795 nakreślił w swym szkicawniku dokładny kształt obu grobowców i napisy. Grób Godfryda miał napis łaciński o prostym brzmieniu:

Tu spoczywa ksiązę Godfryd z Bouillonu, który caty ten kraj zdobyt dla wyznania chrześcijańskiego. 
Niech jego dusza króluje razem z Chrystusem. Amen.

Napis na grobie Baudouina I brzmiał emfatycznie:

Król Baudouin, drugi Judasz Machabeusz, nadzieja Ojezyzny ramię Kościoła - cnota ich obojga - któremu Cedar i Egipt, Dan i Damaszek mężobójczy przynosily ze drżeniem dary swe $i$ daniny,

jest zamkniẹty $\vec{w}$ tym ciasnym grobie.

Nic $z$ tych wspaniałych nagrobków dziś nie pozostało. Słusznie więcpowiadają, że kamień nie jest wieczny.

- Ale pieśń jest wieczna.

Codzień o godzinie 16-tej pielgrzymi idąc procesjonalnie z zapalonymi świeoami za OO. Franciszkanami - strażnikami miejsc świętych - śpiewają pieśni uświęcone tradycją i obchodzą pamiątki męki Pańskiej, zgromadzone tu $z$. różnych stron w czasach, kiedy z powodu prześladowan nie mogli ich czcić poza obrębem Świątyni. Podczas tego obchodu pielgrzymi klękają po kolei przed rzekomym więzieniem Pana Jezusa, dalej przed kolumną biczowania, później idą po schødach na Kalwarię i modlą się u stóp Krzyża, by uczcić Kamień Namaszczenia, po czym wchodzą do Grobu Świętego. Procesję tę kończą u’š́topni ołtarza, gdzie według podania Chrystus Pan po Swym zmartwychwstaniu ukazal się Matce Swojej.

Klęcząc śpiewają:

O Matko Chrystúsowa - raduj się!

Ten, któregoś widziała skazanym, powstat $z$ martwych, jak sam to zapowiedziat!

Raduj się!

- Ten, któregoś widziała przebitego gwoździami, powstal $z$ martwych, jak sam to zapowiedzial!

Raduj się!

Ten, któregoś widziała umierajacego, powstat $z$ martwych, jak sam to zapowiedzial!

Raduj się!

Ten, któregoś widziala niesionego do grobu, powstal $z$ martwych, jak sam to zapowiedzial!

Raduj się stodka Matko Chrystusowa!

Ten, któregoś widziala, jak Go chwala opuszczala, powstal $z$ martwych, jak sam to zapowiedzial!

Rozlega się: ,O salutaris Hostiá. 
Ręce kapłana wznoszą Przenajświętszy Sakrament i kreślą nìm krzyż nad głowami obecnych i nieobecnych.

O godz. 18 dwaj Arabowie znów zamykają odrzwia jedynychı wrót, by je otworzyć następnie o godzinie 6 rano.

Przez całą noc OO. Franciszkanie pełnią straż w Bazylice. Czuwają. Gdyby nie to, schizmatycy zawładnęliby ołtarzami katolickimi, bronionymi przez tyle wieków.

Nad czuwającymi góruje wspaniała postać obecnego proboszcza Bazyliki. Jest nim ujmujacy O. Marian. Jugosłowianin, nasz szczery przyjaciel.

Już o godzinie 2-giej Ojcowie wychodzą ze mszami.

Przejmująca cisza nocna wśród dalekich i bliskich mroków świątynnych rozpraszanych chybotliwym światłem świec wywołuje szczególne wrażenie. Te czeluście mroków i te jarzące światełka są symbolem warunkow, w jakich sprawuje się Przenajświętsza Ofiara w miejscu jej dokonania. Już bowiem o brzasku dnia rozlegają się hałasy krzykliwych Greków, Ormian i Koptów, którzy charkotliwym jazgotem i niesamowicie wrzaśkliwym śpiewem usiłują zagłuszyć jedni drugich.

Ostatnia Msza św. katolicka o godz. 8 w dnie pewszednie, a o godz. 10-tej w święta kończy te nabożeństwa codzienne.

Co się dzieje dziś w Bazylice - nie wiemy. Korespondencja przer wana. Gazety donosiły, że Bazylika została trafiona kilka razy przez pociski przy zbombardowaniu Starego Miasta. Stan wojny zażartej trwa nadal. Bombardowania nie ustają. Pomimo to chronią się ludzie w Bazylice w dalszym ciągu w nadziei, że Grób Święty zostanie uszanowany, że więc tylko tu jeszoze moga znaleźć swe ocalenie. Cuekają i spodżiewają się, że chrześcijanie całego świata staną w obronie Miejsc Świętych, a wtedy ujmą się też i za nimi.

Stan więc dziś Grobu Świętego i położenie Miejsc Świętych jest rozpaczliwe, ale nie tylko $\mathrm{z}$ powodu obecnej wojny wśród dwóch narodów semickich.

Obraz zwykłego, codziennego życia Bazyliki, jaki tu przedstawiłem, jest wzięty z okresu przedwojennego.

Ujawnia nam on tradycję o wiele większą i głębszą, niż latające pociski i strach przed przemocą fizyczną. Stawia nas przed faktem, że w Palestynie, a zwłaszcza w Jerozolimie, istnieją i przejawiają się tak jaskrawo, jak nigdzie w świecie, przeciwieństwa i nienawiści nasowe. polityczne i religijne jednych przy całkowitej obojętności drugich. 
Stwarza to wręoz dziką i wrogą atmosferę, w której kult Ziemi Świętej i Miejsc Ś więtych dusi się i zamiera.

Co jednak mogłoby zmienić tę atmosferę, stłumić nienawiść, przeciwdziałać obojętności?

Ewangelia.

Wszak Ziemia „Święta" czerpie swoją „świętośćc z Pisma św., z Ewangelii, tylko więc na niej opiera się jej znaczenie. Tymczasem Ewangelia, jak w katolickiej Polsce, tak również i w Palestynie, w istocie swej nie jest znana. I tak jak za życia Chrystusa czczono Go powierzchownie, tak też i kult pamiątek po Nim jest przeważnie tylko zewnętrzny. Ziemia Święta spożytkowywana przez ekspedycje naukowe, szkoły i instytuty, jako laboratorium archeologii biblijnej, nie stała sie dotąd ośrodkiem wielkiej akcji - Apostolstwa Ewangelii, nie stworzyła dotąd dla rzesz pielgrrzymich i dla świata szkoły, która by uczyła właściwych dróg poznawania Ewangelii od jej strony wewnętrznej, chrystologicznej, dogmatycznej i moralnej. Można wprawdzie w Jerozolimie, zresztą tak samo, jak i w Polsce, kupić egzemplarz Ewangelii, ale staje się to bez pożytku, ludzie wszak nie umieją z niej korzystać, dalecy są od tego, by się jej radzić, znajdować w niej mądrość życiową i kierownictwo.

A kto bez głęsszej znajomości Ewangelii zwiedzał Miejsca Święte, dla tego stawały się one nieraz powodem zgorszenia lub, co gorzej, zobojętnienia.

Totez jeden z biskupów francuskich, przybyły z liczną pielgrzymką, powiedział po jej zakończeniu: ,Nigdy się już nie podejmę prowadzenia masowej pielgrzymki $z$ mego kraju. Moi diecezjanie nie są do tego przygotowani duchowo. Ich słabej wiary nie chce narażać na zgorszenia“".

Skoro w Ziemi Świętej istota jej świętości — Ewangelia — tak mało jest brana pod uwagę i tak powierzchownie traktowana, cóż dziwnego, że dla większości ludzi ta Ziemia przestaje być Świętą?

Radykalny i powszechny nawrót do Ewangelii takiej, jak ją Święci w Kościele głoszą, jej dokładna znajomość i życie według niej, jest. nie tylko warunkiem pelnego rozkwitu chrześcijaństwa, ale i podstawa! dla obrony jego dorobku historycznego i jego świętych pangiątek.

Umiejętnie zaś zorganizowane i dobrzê prowadzone Ápostolstwo Ewangelii, do którego nawołują począwszy od Leona XIII wszyscy współcześni papieże, wymaga:

1) Wprowadzenia nauki Ewangelii i Nowego Testamentu jaka przedmiotu obowiązkowego do wszystkich szkól. 
2) Połączenia życia parafialnego z Apostolstwem „Ewangelii““.

Pirzy ży:wej, świadomej akcji Apostolstwa Ewangelii, poprzedzonej gruntownym, planowym przygotowaniem, znikłby analfabetyzm religijny. w ciągu jednego pokolenia, a Ziemia Święta stałaby się Ojczyzną duchową każdego, stokroć wartą obrony, gdyż nie chodziłoby już tylko o palestyńskie kamienie, lecz o „wodę żywą“, którą każdy umiałby sam z nich wywołać odpowiednim dla każdego kamienia zawołaniem. Każde wzgórze, dolina każda znalazłyby w myśli i w sereu żywy oddźwięk.

S, L. GRABIANKA.

\section{PROROCTWO DANIELA \\ 070 TYGODNIACH W EGZEGEZIE OSTATNIEJ DOBY}

Często wspomina się o tym, że Daniel przepowiedział dokładnie czas przyjścia Mesjasza. W niniejszym artykule chcę naświetlić ten problem, uwzględniając szczególnie najnowsze poglądy egzegetów. Na wstępie przytaczam tekst przepowiedni według hebrajskiego wydania masoreckłrego oraz główne różnice Wulgaty łacińskiej i tłumaczenia Septuaginty:

Dn. IX. w. 24:

„Siedemdziesiat tygodni wyznaczono dla ludu twego i dla grodu twego świętego, dopóki się nie dokończy przestẹpstwo i nieprawość i nie zgladzi winy, dopóki nie przywiedzie się sprawiedliwości wiecznej i nie zatwierdzi widzenia i proroka oraz namaści świętość najświętszą.

w. 25:

A tak wiedz i rozumiej: Od wyjścia słowa, by prz̧ywrócić i zbu dować Jeruzalem az do pomazańca wodza tygodni siedem, a podczas tygodni szesćdziesięciu dwu znowu bẹdzie zbudowany plac i fosa, a to w) czasach nader trudnych.

w. 26:

A po tygodniach sześćdziesięciu dwu zostanie zgladzony pomazaniec i nic mu (nie zostanie? *) A miasto i światynię zburzy lud wodza, który przyjdzie, którego koniec wpostród zalewu; a spustoszenie to postanowione az do końca wojny.

") Tekst jest w tym miejscu zepsuty. 